\title{
EXCURSION TO NUTFIELD AND REDHILL (LOWER GREENSAND BEDS).
}

\author{
Saturday, May 25Th, I9I8.
}

\author{
By A. Hubert Cox, M.Sc., Ph.D., F.G.S., Director of \\ the Excursion.
}

A PARTY numbering about 35 arrived at Nutfield Station at 3.30. From the station, which lies on the plain made by the Weald Clay, the party followed the lane leading up the escarpment caused by the Hythe Beds of the Lower Greensand formation. Various exposures of the variegated glauconitic sands, with highly irregular concretionary veins of iron-ore. were seen in cuttings along the sunken lane. Higher up the hill and immediately above the junction of two lanes, one of the sand beds contains numerous little pebbles, mostly either vein-quartz or lydianite. The pebbles rarely exceed a quarter of an inch in diameter and are as a rule smaller than this. Up to this point the sands are usually false-bedded and incoherent, but a few feet above the "pebble-bed" the bedding becomes more regular and the beds more cemented. These harder beds form the summit of the escarpment, and they probably represent the horizon at which the cherts are developed at Tilburstow Hill, two miles to the east.

The party then crossed the high road on the crest of the scarp, and entered Nutfield Park, which is situated on the dip slope. A fine view was obtained across the Gault valley to the opposing Chalk escarpment. On descending the dip slope, the beds, which immediately overlie the Hythe Sands, are seen to be well exposed in deep and extensive excavations. The sequence is as follows:-

iii. Clayey glauconitic sands $\quad \ldots \quad \ldots \quad$ 2oft. seen

ii. Mottled bluish calcareous sandstones weathering grey, with interbedded seams of fuller's earth $\quad . \quad \ldots \quad \ldots \quad$.. $\quad$. .

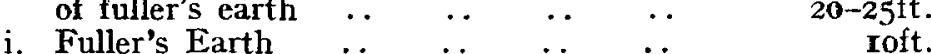
The whole series dips down the hill at an angle of 3 to $5^{\circ}$.

The director referred to the limited distribution of the Fuller's Earth Beds, and explained the difficulty of making any accurate correlation of the strata comprising this local facies with those of the Kentish coast - the Sandgate Beds-that presumably occupied the corresponding stratigraphical horizon. The calcareous sandstones (ii.) are fossiliferous, but the species occurring have mostly a relatively long range, so that the assemblage is rather indefinite. He then described the special features of 
Fuller's Earth, which is a very fine-grained clay occurring interbedded with coarse-grained sands and sandstones that were evidently deposited in shallow water, as shown by the coarseness of the sand grains and by the frequent occurrence in the sandstones of plant remains (mostly drift-wood). The deposits were evidently laid down during a period of gentle subsidence, since the Wealden Beds below the Lower Greensand represent a fresh-water formation, whereas the strata associated with the Fuller's Earth, contain a marine fauna. Fuller's Earth, when examined microscopically, presents certain features that at once distinguish it from ordinary detrital clays, and the director expressed his opinion that it represents a true precipitate; this would account for such an extremely uniform and finegrained deposit occurring interbanded with coarse sands. He referred to occurrences of Fuller's Earth at other stratigraphical horizons in other parts of the country, and he pointed out that in whatever formation it occurs, it is always associated with sandy limestones or highly calcareous sandstones, just as at Nutfield.

The party descended the pit and inspected the Fuller's Earth more closely. Its fine-grained character was noted, and it was seen to be greenish blue in colour when unweathered, with occasional indications of bedding. Joint surfaces were strongly iron-stained. Specimens of barytes with associated quartz were collected from large concretionary masses that occur sporadically in the Fuller's Earth. The concretions are of large size, being often two feet in diameter. Externally they are roughly circular, but flattened vertically. Internally they consist of quite coarsely crystalline barytes, pink and white in colour, from which occasional crystals, almost perfect, may be broken out. Quartz occurs intermingled with, but of subsequent formation to, the barytes.

A few fossils were obtained from the overlying calcareous sandstones (ii.). They included specimens of Enallaster fittoni, Terebratula sella, Hoplites cf. deshayesi, Cyprimeria, etc. Further specimens of very large ammonites and nautiloids were inspected, but proved too weighty for the collecting-bags of even the most enthusiastic palæontologists.

Before leaving the quarry the attention of the party was drawn to a curious Pleistocene channel which cuts through the glauconitic sands (iii.) and is infilled with clay containing angular flints.

Leaving by the lower end of the quarry, the party then proceeded westwards past old overgrown workings to the northern end of the Park Pits. The general succession was seen to be similar to that in the pit previously visited, except that the calcareous sandstones (ii.) had increased in thickness. The walk was continued westwards along field paths near the bottom 


\section{I52 A. H. COX, EXCURSION TO NUTFIELD AND REDHILL.}

of the dip slope until a third pit situated about half a mile east of Redhill Station was reached. This pit was briefly inspected, the sequence proving similar to that at Nutfield, except for minor variations in the thicknesses of the beds. Additional specimens of barytes were collected, and a good example of the result of contemporaneous erosion was observed near the western end of the section. The walk was then continued into Redhill, where tea was obtained. The President, Mr. J. F. N. Green, expressed the thanks of the party to the director of the excursion. Mr. A. H. Williams, F.G.S., acted: as Excursion Secretary.

\section{REFERENCES.}

Geological Survey Map, Old Series, $\mathrm{i}$-inch, Sheet 8 .

Ordnance Map Iin., Sheet I 26 (large sheet series).

Ordnance Map, 6in., Surrey, 26 S.E. and 27 S.W.

r875. TOPLEY, W.- "Geology of the Weald," Mem. Geol. Surve\%.

1894. Meyer, C. J. A.- "Excursion to Redhill and Nutfield," Proe. Geol. Assoc., vol. xiii., p. $37 \mathrm{r}$.

I895. Leighton, T.- "The Lower Greensand of East Surrey," Quavt. Journ. Geol. Soc., vol. li., p. IoI.

rgio. Herries, R. S. - "The Weald," Geology in the Field, vol. ii., p. 442.

1915. Cox, A. H.- "Excursion to Tilburstow and Godstone," Proc. Geol. Assoc., vol. xxvi., p. 123.

I9r5. Cox, A. H.- "Excursion to Tilburstow and Nutfield," Proc. Geol: Assoc., vol, xxvi., p. 324 .

19I6. Davies, G. M.- "Rocks and Minerals of the Croydon Area," Proc. Croydon Nat. Hist. Soc., 19r 5-16, p. 58. 